\title{
IMPROVING MANAGEMENT PRACTICES OF EMERGING CATTLE FARMERS IN SELECTED AREAS OF THE EASTERN CAPE PROVINCE: THE ROLE OF AGRICULTURAL EXTENSION
}

\author{
Katikati, A. ${ }^{1}$ and Fourie, P. J. ${ }^{2}$
}

Correspondence Author: A. Katikati. Email: aphiwekatikati@gmail.com

\begin{abstract}
The study was conducted to determine cattle production and management practices of developing cattle farmers in two selected districts (Amathole and Chris Hani) in the Eastern Cape Province of South Africa. The study mainly focused on beef cattle farmers that are farming on leased or private land. From both districts, 60 respondents (30 per district) were interviewed using structured questionnaires. Results showed that $33 \%$ of the study sample had low levels of education while only $15 \%(n=10)$ had tertiary education qualifications. Cattle management activities were performed by almost all the respondents except deworming which was done by only 33\%. The respondents were mostly vaccinating for diseases such as Black quarter (42\%), Redwater (40\%), and Anthrax (30\%). The assessed farmers were controlling parasites with many different methods, however, pour on was found to be the most frequently used method (52\%), followed by plunge dipping (33\%) and hand spray (32\%). There were farmers that planted cultivated pastures (35\%) and some that were also using supplements (licks) for their herds (77\%). As bush encroachments were not a problem in some farms, most farmers were not taking any actions, but $24 \%$ were using fires when reducing moribund. Breeding monitoring activities (birth observation, pregnant test and bull futility testing) were conducted by the respondents $(78 \%, 15 \%$ and $12 \%$ respectively). It is recommended that agricultural extension play an imperative role in linking possible role players and farmers.
\end{abstract}

Keywords: Eastern Cape, cattle management, emerging farmers

$\begin{array}{ll}\text { ABBREVIATIONS AND ACRONYMS } \\ \text { DAFF } & \text { Department of Agriculture, Forestry and Fisheries } \\ \text { ECSER } & \text { Eastern Cape State of the Environment Report } \\ \text { EU } & \text { European Union } \\ \text { GDP } & \text { Gross Domestic Product } \\ \text { GRSA } & \text { Government of the Republic of South Africa } \\ \text { PD } & \text { Pregnancy Diagnosis } \\ \text { RPO } & \text { Red Meat Producers Organisation } \\ \text { RSA } & \text { Republic of South Africa } \\ \text { SABMVC } & \text { South African Beef Market Value Chain } \\ \text { SAI } & \text { South Africa.info } \\ \text { SAS } & \text { Statistical Analysis Software }\end{array}$

\footnotetext{
${ }^{1}$ Department of Agriculture, Central University of Technology, Free State, Private Bag X20539, Bloemfontein, 9300, Republic of South Africa. Email: aphiwekatikati@gmail.com

${ }^{2}$ Department of Agriculture, Central University of Technology, Free State, Private Bag X20539, Bloemfontein, 9300, Republic of South Africa. Email: pfourie@cut.ac.za
} 


\section{INTRODUCTION}

According to Sejian et al. (2012:20), animal production is the most vital component of world agriculture as people are mostly dependent on domestic animals for many important needs (meat, fat, milk, and other dairy products, eggs and fibres like wool or cashmere) as well as for other purposes such as transport, draft power, and provision of fertilizers, especially in developing countries. In 2008, it was stated in the South African Information website that South Africa produces $85 \%$ of its meat requirements while the other portion (15\%) is imported from other countries like Namibia, Botswana, Swaziland, Australia, New Zealand and the European Union (EU) (South Africa Info (SAI), 2008:01). However, Musemwa et al. (2008:239) found that cattle production contributed approximately $25 \%$ and $30 \%$ to the national agricultural Gross Domestic Product (GDP).

Provinces that are dominated by cattle farms include the Eastern Cape, parts of the Free State, KwaZulu-Natal, Limpopo, and the Northern Cape (Department of Agriculture, Forestry and Fisheries (DAFF), 2011:6). It has been documented that in South Africa, almost 50000 commercial farmers own 8.2 million cattle, while 240000 smallholders and three million subsistence farmers own 5.6 million cattle (DAFF, 2011:6). The Eastern Cape Province is one of the lowest beef producing (6\%) provinces (DAFF, 2011:4), even though it was found to have a higher number of cattle than other provinces in South Africa (DEPARTMENT OF AGRICULTURE, FORESTRY AND FISHERIES, 2012:01). The South African beef industry is divided into subgroups according to resource availability, method and scale of production, namely large commercial, emerging, and the communal farmers (Scholtz et al., 2008:2). Smallholder farms are challenged with limited access to land, scarcity of water and marketing channels, smaller herd size, animal diseases, theft (Montshwe, 2006:70), high transaction costs (Musemwa et al., 2008:241), and degradation of rangelands (GRSA, 2007:22). Emerging farmers are known for using traditional production techniques, lacking with institutional capacity and support and they have small farms that are labour-intensive. Most of them are based in the former homeland areas and there are very few of them that market their produce (Pienaar \& Traub, 2015:4). The current study was carried out to assess the management practices of developing cattle farmers in the two selected districts of the Eastern Cape Province. Furthermore, the contribution that agricultural extension can make in the development of these farmers will also be highlighted.

\section{MATERIALS AND METHODS}

The study was conducted at Amathole and Chris Hani Districts in the Eastern Cape Province of South Africa. This province is the second largest in the country (South African Government, 2017:01), and it has well established agriculture as commercial and subsistence farming are practised. The province has Karoo areas where extensive farming (game and livestock) is mostly done (Eastern Cape State of the Environment Report (ECSER), 2009:01). The respondents were the emerging cattle farmers who farm on private or leased land. Since both selected districts had eight municipalities each, there were two municipalities on each who had no farms and were not considered. Therefore, 12 municipalities (six from each district) were selected where five respondents were selected from each municipality, providing a total of 60 farmers for the study. Structured questionnaires were used to collect data and respondents were individually interviewed. Factors that were investigated included details of the farmer, herd information, and assessments of financial and animal land management. The collected data 
were captured in Microsoft Office Excel. Before the analysis took place, the data was cleaned and then analysed using the Statistical Analysis Software programme.

\section{RESULTS AND DISCUSSION}

\subsection{Educational level}

There were $14(23.3 \%)$ respondents with no education while six (10\%) had grade 1-6. Only three $(5 \%)$ farmers had degrees in agriculture. The level of education is directly related to the success of a farm and it influences their decision making (Lubambo, 2011:30). With regards to marketing, educated farmers prefer abattoirs while ones with no education prefer private buyers (Musemwa et al., 2007:131). Performance based on level of education and income generated from cattle farming only is also shown. A high average (23.4 \pm 33.84$)$ number of cattle sold was found on farms with grade 1-6, however, farms with agricultural qualifications had the highest average income (R109 666.70). In Table 1, age and farming experience averages of respondents are shown. The age of the farmers is regarded as a crucial factor for the success and sustainability of a farm as it indicates some farmer's variables, in other words, the level of decision-making and interest (Lubambo, 2011:28). Experience in farming has been found to have an influence in selecting marketing channels (Musemwa et al., 2007:01). Yeamkong and colleagues (2010:814) found that longer experience in dairy farming had increased monthly milk yield and revenue in Thailand. Extension could possibly play a role in the improvement of the general farming knowledge of these farmers by connecting them with the agricultural industry and academic institutions. The provision of service learning by universities may also provide a solid platform in enhancing the knowledge of these farmers.

Table 1: Educational level and performance of emerging cattle farmers in Amathole and Chris Han, Eastern Cape

\begin{tabular}{|l|c|c|c|c|c|}
\hline \multirow{2}{*}{$\begin{array}{l}\text { Level of } \\
\text { education }\end{array}$} & $\begin{array}{c}\text { Proportion } \\
\text { of } \\
\text { respondents }\end{array}$ & \multicolumn{2}{|c|}{$\begin{array}{c}\text { Number of sold } \\
\text { animals }\end{array}$} & \multicolumn{2}{c|}{ Animal sales (R) } \\
\cline { 3 - 7 } & $14(23 \%)$ & $14.31 \pm 12.43$ & 186 & $129015.4 \pm 261356.62$ & 1677200 \\
\hline No Education & $6(10 \%)$ & $23.4 \pm 33.84$ & 117 & $90040 \pm 132098.19$ & 450200 \\
\hline Grade 1-6 & $27(45 \%)$ & $16.74 \pm 24.95$ & 385 & $75100 \pm 101227.4$ & 1877500 \\
\hline Grade 7-12 & $3(5 \%)$ & $16 \pm 16.52$ & 48 & $109666.7 \pm 74676.52$ & 329000 \\
\hline Agric. Degree & $10(17 \%)$ & $17.29 \pm 12.39$ & 121 & $86857.14 \pm 58924.18$ & 608000 \\
\hline $\begin{array}{l}\text { Other } \\
\text { qualification }\end{array}$ & \multicolumn{2}{|c|}{ Age (years) } & \multicolumn{3}{|c|}{ Farming Experience } \\
\hline & \multicolumn{2}{|c|}{$55.11 \pm 14.93$} & \multicolumn{3}{|c|}{$11.91 \pm 7.65$} \\
\hline
\end{tabular}

\subsection{Cattle management activities}

The entire group of farmers was practising activities listed in Table 2 on their farms, except for deworming which was only being practised by $33 \%$ of the sample. Only $2 \%$ of the respondents were not branding livestock, while almost all other activities were done throughout the year, except for those farmers who were deworming in summer. Even though castration was mostly done in all seasons (58\%), some farmers were castrating in winter (20\%). In bulls, castration 
helps in preparing them for market, since steers are usually the most frequently targeted for selling or slaughter (Musemwa et al., 2007:01). The results show that respondents had an idea about cattle management activities, however, there is still a lack of knowledge on when a specific activity must be carried out. This gap should be bridged by agricultural extension in collaboration with agricultural research, breeders' society and industry. Even commercial farmers have become more willing to assist in the development of emerging farmers.

Table 2: Cattle management activities of emerging cattle farmers in Eastern Cape

\begin{tabular}{|l|c|c|c|c|c|c|}
\hline \multirow{2}{*}{ Management activities } & \multicolumn{7}{|c|}{ Proportion of respondents \& seasons (\%) } \\
\cline { 2 - 8 } & Summer & Autumn & Winter & Spring & Throughout & Total \\
\hline Castration & 8 & 10 & 20 & 4 & 58 & 100 \\
\hline Dehorning & 10 & 13 & 16 & 3 & 58 & 100 \\
\hline Deworming & 15 & 9 & 2 & 7 & - & 33 \\
\hline Ear tagging & 4 & 7 & 4 & 2 & 83 & 100 \\
\hline Branding & 5 & 7 & 9 & - & 77 & 98 \\
\hline Treating sick animals & - & 2 & 5 & - & 93 & 100 \\
\hline Sorting calves & - & - & 8 & 4 & 88 & 100 \\
\hline Vaccinating & 4 & 6 & 8 & 2 & 80 & 100 \\
\hline
\end{tabular}

\subsection{Animal health and nutrition}

Vaccination and tick control are mostly carried out as government services unlike other poorly executed practices (deworming) (Nowers, Nobumba \& Welgemoed, 2013:49). In this study, $88.3 \%$ of respondents were vaccinating while $11.7 \%$ were not. Most vaccinated diseases were Black quarter (42\%), Redwater (40\%) and Anthrax (30\%), while Trichomonas (2\%), Pulpy kidney $(2 \%)$ and Footrot $(2 \%)$ were the least vaccinated diseases. Some respondents were just vaccinating animals without knowing the specific diseases. To reduce occurrence of illness in a cattle herd, there should be an implementation of sound vaccination programmes, parasite control, and frequent herd observation. Through non-formal education, extension services could facilitate these farmers on how livestock vaccination should be followed based on geographical location and season of the year. In an extension approach, companies selling animal health and feed products could be mobilised to eventually become more involved in rural communities.

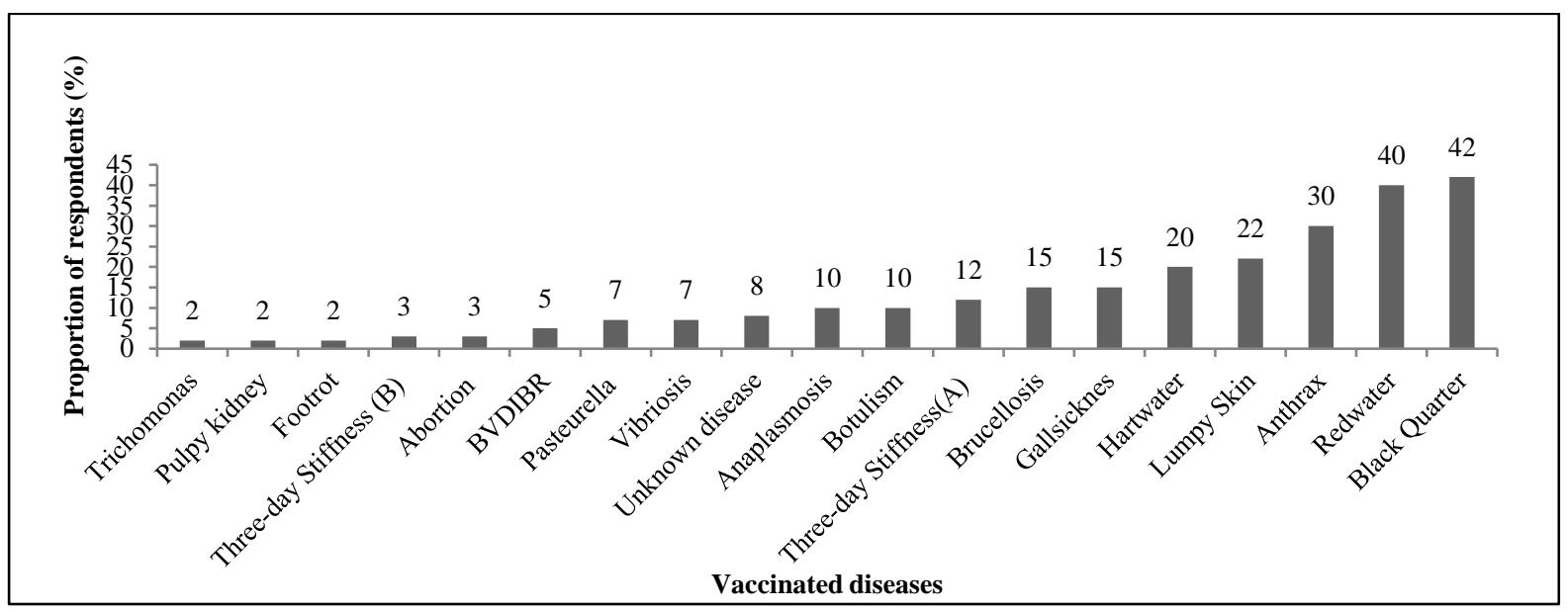


Figure 1: Disease vaccinated by respondents

\subsection{Parasite control}

The most frequently used method of parasite control was found to be pour on (52\%), followed by plunge dipping (33\%) and hand spraying (30\%), while $16 \%$ were using spot treatment, injectable parasiticides and dosing (Figure 2). De La Fuente et al. (1998:1) stated that external parasite control (ticks) and the transmission of tick-borne diseases remains a challenge for the cattle industry, especially in tropical and subtropical areas of the world. Even though traditional control methods were put in place, parasites still result in severe losses for the cattle farming. It is vital to control these parasites in livestock as they cause diseases and wounds that are predisposed to screwworm infestation and damaged teats in cows (Moyo \& Masika, 2009:01). From the results of the current study there is evidence that a substantial proportion of respondents (82\%) were controlling internal parasites while only $18 \%$ were not controlling it at all (Figure 3). Worldwide internal parasites are a continuous problem, however grazing management strategies and biological control have been proven to be effective non-chemical parasite control methods (Waller, 2006:277). Internal parasites cause deficient performance and occasionally lead to death in young animals; they damage internal organs and subsequently affect the digestion (Williams \& Loyacano, 2001:9).

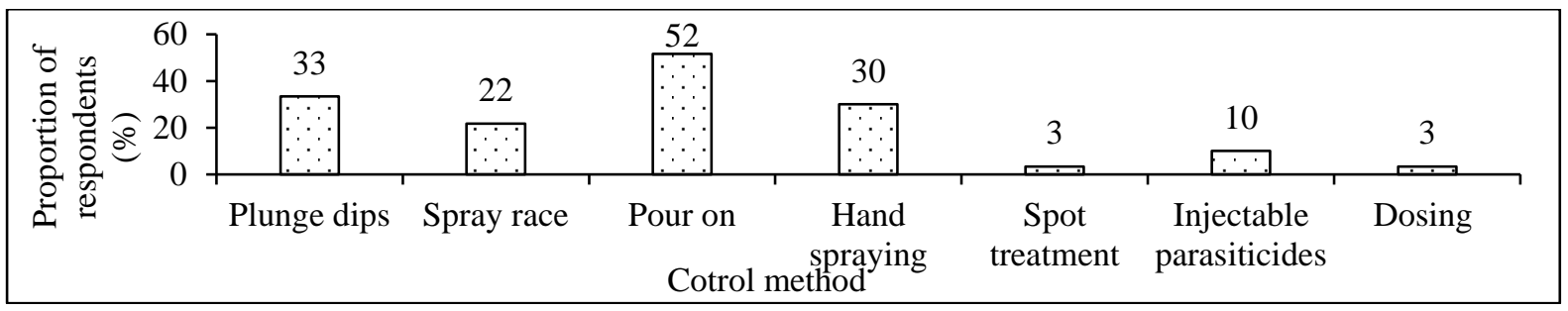

Figure 2: External parasite control

\subsection{Cattle supplementation (licks)}

Most of the respondents (77\%) were supplementing their animals, while $23 \%$ believed that supplements are expensive, and only $2 \%$ indicated that they did not know anything about licks. Some respondents were supplementing throughout the year $(58 \%)$ while most of them were only supplementing in winter (13\%). Van Pletzen (2009:01) documented that there is a lick supplementation programme that was developed to correct the deficiencies or imbalances in specific areas. There are limited elements on natural veld in certain seasons (phosphate and trace elements). For instance, in winter, veld intake in cattle decreases as digestibility, palatability and protein content decreases. Winter supplementation (protein) prevents losses of weight in livestock while summer licks maximise growth (Van Pletzen, 2009:01). This type of information needs to be emphasised to the farmers. 


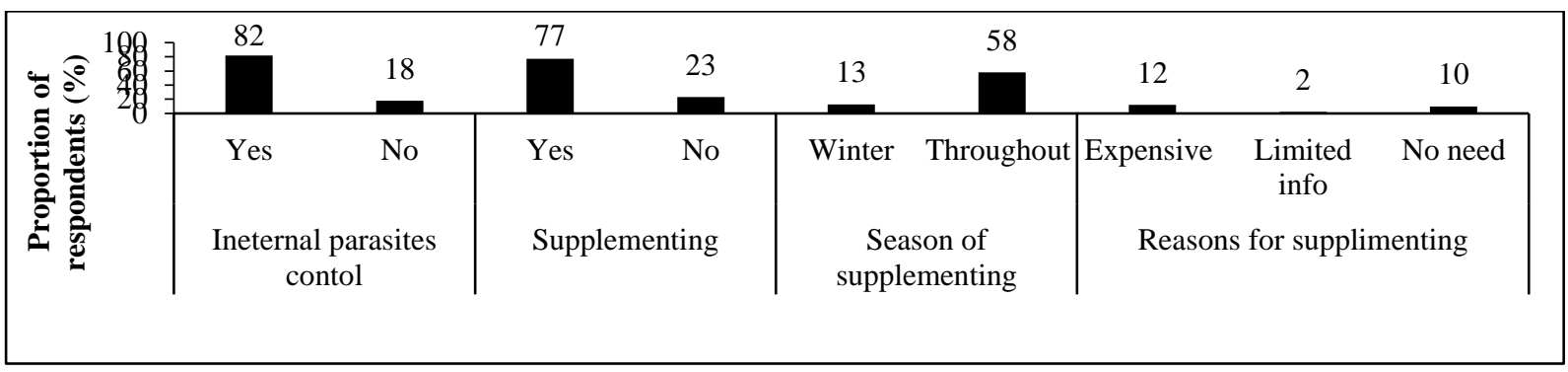

Figure 3: Proportion of respondents on internal parasites, animal supplementing, season of supplementing and reasons for supplementing

\subsection{Veld management}

Half $(50 \%)$ of the farmers kraal (cattle enclosure) their animals at night. Farmers are kraaling their stock in order to prevent theft, road accidents, and crop damage, as well as to minimise disease and parasite control (Nthakheni, 1993:01). However, day grazing and night kraaling are mostly practised in communal areas (Kunene \& Fossey, 2006:01). However, cattle add some organic matter back to the field. The majority of respondents $(76 \%)$ had camps while $23 \%$ do not have any. Livestock farms that are not divided into camps are prone to uncontrolled breeding, spread of diseases and undesirable bull to cow ratio (Sekwadi, Maboa \& Maqashu, 2016:50). Camps (fencing) in a farming environment help in reducing labour expenses. The management of grazing, breeding, diseases, parasites, trespassing, theft and predation become more practical (Moyo et al., 2008:01). Most of the respondents (71\%) were found to be performing rotational grazing while $29 \%$ were following continuous grazing. Since rotational grazing requires a high work load and a lot of fencing, it requires more finances (Tainton, 1999:173). Rotational grazing is predicted to increase grass production during the year of grazing, and prevent grassland growing out and losing quality (Fynn, 2012:01). Foster (2015:15) listed continuous grazing as one of the harmful rangeland management practices. Furthermore, $35 \%$ of respondents had cultivated pastures on their farms (Figure 4). The reason for this might be due to the high establishment cost of cultivated pastures. When cultivated pastures are limited, herd productivity becomes low, regardless of the potential of the breed. The establishment and maintenance of pastures is expensive, but it improves security and allows easy access to obstacles like intense bush; and it also improves the value of the farm (Siegmund-Schultze et al., 2007:01). These facts need to be brought to the farmers' attention as it might encourage them to follow rotational grazing. As natural veld is the major source of feed for emerging farmers, extension agents need to ensure that farmers are managing their grazing well through training and supervision. Even in this situation, extension could serve as a valuable link between academic institutions and farmers as universities are frequently searching for sites where practical demostrations can be presented.

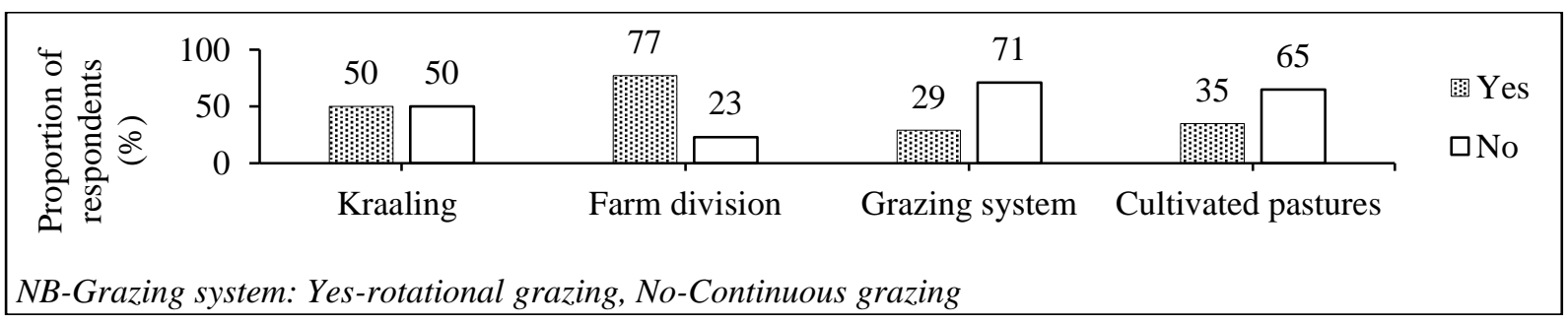

Figure 4: Cattle kraaling, veld division and grazing system 


\subsection{Moribund and bush encroachment management}

More than half of the respondents (74\%) were not taking any means against bush encroachment while $24 \%$ were burning for controlling moribund (Table 3 ). The results of the current study are in line with those of Mahlobo (2016:20) who stated that fire is used to remove dry and dead plant materials, for initiating new lushes of grass, for eradicating ticks, tsetse flies and other insects or pests harmful to livestock, and for harvesting forest honey. However, veld burning has destroyed plant residues that would have helped for winter grazing and enhanced the degradation of the land in South Africa. Many respondents (32\%) were not taking control or preventative measures to limit bush encroachment while $18 \%$ were removing it mechanically (Table 3). This encounter can be caused by a shortage of rainfall, notably wet cycles, heavy grazing, absence of hot brush killed fires, loss of large trees, and soil nutrient changes. Moreover, some of the woody plants add value to browsing for livestock (Solomon, Snyman \& Smit, 2007:489).

Table 3: Measures to control bush encroachment and moribund

\begin{tabular}{|l|c|c|}
\hline \multirow{2}{*}{ Control methods } & \multicolumn{2}{|c|}{ Proportion of respondents (\%) } \\
\cline { 2 - 3 } & Bush encroachment & Moribund \\
\hline No action & 32 & 74 \\
\hline Allow surrounding households to take trees & 4 & \\
\hline Spraying (Chemical) & 2 & \\
\hline Mechanically remove & 18 & \\
\hline Spraying and mechanically remove & 5 & 24 \\
\hline Hire aerial spraying & 4 & \\
\hline Burning & 5 & 3 \\
\hline No encroachment of undesirable plants & 32 & \\
\hline Unplanned fires sometimes & & \\
\hline
\end{tabular}

\subsection{Livestock breeding management}

The proportion from the study sample that were doing the parturition observation, pregnancy and fertility testing, season breeding and own bull breeding were 78\%, 15\%, 12\%, 47\% and $62 \%$ respectively. Matiko et al. (2008:897) stated that smallholders are not practising the pregnant diagnosis in their herds as there is a scarcity of veterinarians and they do not know the Pregnancy Diagnosis (PD) importance in cattle farming. As there is a low portion of respondents that are taking part in these practices, extension services could improve the production and profitability of these farmers through providing non-formal, agriculturally related, continued training and support. The advancement of scientific breeding and the use of breeding values by the Merino breeders' society may be used as a vehicle in extension programmes to promote a more scientific approach. 


\begin{tabular}{|c|c|c|c|c|c|c|c|c|c|c|}
\hline \multirow[t]{3}{*}{$\begin{array}{r}100 \\
50 \\
0\end{array}$} & 78 & 22 & 15 & 85 & 12 & 88 & 47 & 53 & 62 & 38 \\
\hline & Yes & No & Yes & No & Yes & No & Yes & No & Yes & No \\
\hline & \multicolumn{2}{|c|}{$\begin{array}{l}\text { Parturition } \\
\text { Observation }\end{array}$} & \multicolumn{2}{|c|}{ Cows pregnancy tests } & \multicolumn{2}{|c|}{ Bulls fertility tests } & \multicolumn{2}{|c|}{ Breeding seasons } & \multicolumn{2}{|c|}{$\begin{array}{l}\text { Breed your own bulls } \\
\text { to use in your herd }\end{array}$} \\
\hline
\end{tabular}

Figure 5: Cattle breeding enhancement practices

\subsection{Livestock performance}

The assessed farmers had a total of 2861 breeding stock (cows $=74 \%$ and heifers $=26 \%$ ). The conception, calving and weaning rate were $93 \%, 88 \%$, and $82 \%$ respectively. Furthermore, these findings are elevated for the level of farmers as Matiko et al. (2008:01) observed a pregnancy rate of $44 \%$ in emerging farmers and stated that the minimum pregnancy rates in commercial farmers should be approximately $70 \%$. These figures are therefore lower than those of the current study. Comparable results were found by Grobler (2016:59) who found pregnancy rates ranging between $60 \%$ and $93 \%$. Performance of the respondents can be improved by ensuring that cattle management activities are followed and monitored through extension services. Farmers should also be made aware of efficiency benchmarks.

Table 4: The total and percentage of bred cows and heifers from mating until weaning

\begin{tabular}{|l|c|c|c|c|}
\hline \multirow{2}{*}{ Breeding cattle } & Number of animals & \multicolumn{3}{|c|}{ Breeding stock performance } \\
\cline { 3 - 5 } & bred (100\%) & Pregnancy rate & Calving rate & Weaning rate \\
\hline Cows & 1915 & $1763(92 \%)$ & $1674(87 \%)$ & $1550(81 \%)$ \\
\hline Heifers & 946 & $884(93 \%)$ & $850(90 \%)$ & $798(84 \%)$ \\
\hline Total & 2861 & $2647(93 \%)$ & $2524(88 \%)$ & $2348(82 \%)$ \\
\hline
\end{tabular}

\section{CONCLUSION}

Emerging cattle farmers are mostly older people, particularly in this study area, and most of them do not have a tertiary education. With regards to livestock health management, they vaccinate for many diseases, but most respondents vaccinated for Black quarter, Redwater and Anthrax. They were also controlling parasites. Some farmers provided supplementary licks and feeds and had cultivated pastures on their farms. However, there is evidence that farmers had an issue with fencing as they had camps but are still engaging in continuous grazing. In some management practices, our respondents had minimal information about bush encroachment and moribund management. Therefore, the study shows that there is still a role that needs to be played by the agricultural extension services for the developing farmers. In order to improve these farmers' productivity, the agricultural extension agents also need to assist farmers through training in improved farming methods and techniques. In the long term, it could result in better production efficiency and income, better standards of living, and lifting the social and educational standards of rural life. An integrated and well-coordinated agricultural extension programme, driven by a team of trained and knowledgeable specialists in the field of animal production, could render the much-needed momentum towards economic cattle production. Finally, the study recommends that government be responsible for hosting planned workshops 
for farmers in order to equip them with knowledge. In addition, agricultural bodies such as the RPO and breeders' societies could also play a meaningful role in the training of these farmers.

\section{ACKNOWLEDGEMENTS}

National Research Foundation and Central University of Technology for financial assistance are acknowledged. Our sincere gratitude goes to all the farmers who participated during the period of study for their precious time.

\section{REFERENCES}

DEPARTMENT OF AGRICULTURE, FORESTRY AND FISHERIES, 2011. A profile of the South African beef market value chain [viewed 2 April 2016]. Available from: http://www.nda.agric.za/docs/AMCP/BeefMVCP11-12.pdf

DEPARTMENT OF AGRICULTURE, FORESTRY AND FISHERIES (DAFF), 2012. Animal production [viewed: 7 February 2018]. Available from: http://www.daff.gov.za/daffweb3/Branches/Agricultural-Production-Health-FoodSafety/Animal-Production/Livestock-Production

DE LA FUENTE, J., RODRÍGUEZ, M., REDONDO, M., MONTERO, C., GARCÍAGARCÍA, J., MÉNDEZ, L., SERRANO, E., VALDÉS, M., ENRIQUEZ, A., CANALES, M. \& RAMOS, E., 1998. Field studies and cost-effectiveness analysis of vaccination with Gavac $^{\mathrm{TM}}$ against the cattle tick Boophilus microplus. Vaccine, 16(4):366-373.

EASTERN CAPE STATE OF THE ENVIRONMENTAL REPORT (ECSER), 2009. Department of Economic Development and Environmental Affairs [viewed 7 April 2016]. Available from: http://projects.gibb.co.za/Portals/3/projects/200911\%20Eastern\%20Cape\%20Environm ental/State\%20of\%20Environment\%20Report\%20\%E2\%80\%93\%20Work\%20in\%20p rogress $\% 20$ draft.pdf

FOSTER, L.A., 2015. The profitability and production of a beef herd on transitional Cymbopogon - Themeda veld receiving three different levels of supplementation. D Tech Thesis, Central University of Technology.

FYNN, R.W., 2012. Functional resource heterogeneity increases livestock and rangeland productivity. Rangeland Ecol Manag, 65(4):319-329.

GROBLER, S.M., 2016. Alternative management systems to increase beef production under extensive conditions. PhD Thesis, University of the Free State.

GRSA-Government of the Republic of South Africa support to NEPAD-CAADP implementation 2007. TCP/SAF/3002 (I) (NEPAD Ref.07/50 E), pp 22.

KUNENE, N.W. \& FOSSEY, A., 2006. A survey on livestock production in some traditional areas of Northern Kwazulu Natal in South Africa. Livestock Res. Rural Dev., 18:30-33. 
LUBAMBO, P.T., 2011. An appraisal of post-transfer production trends of selected land reform projects in the North-West Province, South Africa, MSc Thesis, University of Pretoria.

MAHLOBO, B.T., 2016. Multi-criteria livestock assessment for sustainability of smallholder farms in Kwa-Zulu Natal. PhD Thesis, Stellenbosch University.

MATIKO, M.K., KANUYA, N.L., WALDMANN, A., ROPSTAD, E. \& REKSEN, O., 2008. Environmental constraints on post-partum ovarian activity in Tanzanian Zebu cows. Theriogenology, 69(7):896-904.

MONTSHWE, B.D., 2006. Factors affecting participation in mainstream cattle markets by small-scale cattle farmers in South Africa. PhD Thesis, University of the Free State.

MOYO, B. \& MASIKA, P.J., 2009. Tick control methods used by resource-limited farmers and the effect of ticks on cattle in rural areas of the Eastern Cape Province, South Africa. Trop. Anim. Health Prod., 41(4):517-523.

MOYO, B., DUBE, S., LESOLI, M. \& MASIKA, P.J., 2008. Communal area grazing strategies: Institutions and traditional practices. Afr. J. Range Forage Sci., 25(2):47-54.

MUSEMWA, L., CHAGWIZA, C., SIKUKA, W., FRASER, G., CHIMONYO, M. \& MZILENI, N., 2007. Analysis of cattle marketing channels used by small scale farmers in the Eastern Cape Province, South Africa. Livestock Res. Rural Dev., 19(9):131.

MUSEMWA, L., MUSHUNJE, A., CHIMONYO, M., FRASER, G., MAPIYE, C. \& MUCHENJE, V., 2008. Nguni cattle marketing constraints and opportunities in the communal areas of South Africa. Afr. J. Agric. Res., 3(4):239-245.

NOWERS, C.B., NOBUMBA, L.M. \& WELGEMOED, J., 2013. Reproduction and potential of communal cattle on sourveld in the Eastern Cape Province, South Africa. Appl. Anim. Husb. Rural Develop., 6:48-54.

NTHAKHENI, D.N., 1993. Productivity measures and dynamics of cattle herds of small scale producers in Venda, MSc Thesis, University of Pretoria.

PIENAAR, L. \& TRAUB, L.N., 2015. Understanding the smallholder farmer in South Africa: Towards a sustainable livelihood classification. In Int. Conf. Agric. Econ., 4.

SOUTH AFRICA INFO (SAI), 2008. [viewed 6 April 2016]. Available from: http://www.southafrica.info/business/economy/sectors/542547.htm\#.VwTES01WHGg

SOUTH AFRICAN GOVERNMENT. 2017. South Africa's provinces [viewed 24 February 2017]. Available from: http://www.gov.za/about-sa/south-africas-provinces

SCHOLTZ, M.M., BESTER, J., MAMABOLO, J.M. \& RAMSAY, K.A., 2008. Results of the national cattle survey undertaken in South Africa, with emphasis on beef. Appl. Anim. Husb. Rural Develop., 1:1-9. 
SEJIAN, V., NAQVI, S.M.K., EZEJI, T., LAKRITZ, J. \& LAL, R., 2012. Environmental stress and amelioration in livestock production, Berlin: Springer.

SEKWADI, C.B.L. MABOA \& A. MAQASHU., 2016. Artificial insemination vs natural breeding in cattle: exploring breeding options for communal farmers in South Africa. ARC Annual Beef Bulletin, 50.

SIEGMUND-SCHULTZE, M., RISCHKOWSKY, B., D.A VEIGA, J.B. \& KING, J.M., 2007. Cattle are cash generating assets for mixed smallholder farms in the Eastern Amazon. Agric. Sys., 94(3):738-749.

SOLOMON, T.B., SNYMAN, H.A. \& SMIT, G.N., 2007. Cattle rangeland management practices and perceptions of pastoralists towards rangeland degradation in Borana zone of Southern Ethiopia. J. Env. Manage., 82(4):481-494.

TAINTON, N., 1999. Veld Management in South Africa. Afr. J. Range Forage Sci., 16(1\&2):126-127.

VAN PLETZEN, H., 2009. Beef production from the veld offers great opportunities [viewed 2 September 2017]. Available from: http://www.voermol.co.za/en/news/technical/BEEF_PRODUCTION_FROM_THE_VE LD_OFFERS_GREAT_OPPORTUNITIES/default.aspx

WALLER, P.J., 2006. Sustainable nematode parasite control strategies for ruminant livestock by grazing management and biological control. Anim. Feed Sci. Technol., 126(3-4):277289.

WILLIAMS, J.C. \& LOYACANO, A.F., 2001. Internal parasites of cattle in Louisiana and other Southern States, Research Information Sheet \#104, pp. 9.

YEAMKONG, S., KOONAWOOTRITTRIRON, S., ELZO, M.A. \& SUWANASOPEE, T., 2010. Effect of experience, education, record keeping, labor and decision making on monthly milk yield and revenue of dairy farms supported by a private organization in Central Thailand. Asian-Australas. J. Anim. Sci., 23(6):814. 